\title{
Benlik İfade Eden Marka, Marka Aşkı, Pozitif Ağızdan Ağıza İletişim ve Marka Sadakati Arasındaki İlişkinin İncelenmesi: Paketlenmiș Ürün Kategorisinde Bir Araştırma \\ Sinan CAVUSOĞLU ${ }^{1}$ Bülent DEMIRAĞ $\breve{G}^{2}$
}

\begin{tabular}{ccc}
\hline $\begin{array}{c}\text { Geliş Tarihi/ Received } \\
09 / 04 / 2020\end{array}$ & Kabul Tarihi/ Accepted & Yayın Tarihi/Published \\
$02 / 06 / 2020$ & $15 / 07 / 2020$ \\
\hline Citation/Atıf: Çavuşoğlu, S. ve Demirbağ, B., (2020), Benlik Iffade Eden Marka, Marka Aşkı, \\
Pozitif Ağızdan Ağlza Iletişim ve Marka Sadakati Arasındaki İlişkinin Incelenmesi: \\
Paketlenmiş, Ürün Kategorisinde Bir Araştırma, Atatürk Üniversitesi İktisadi ve İdari Bilimler \\
Dergisi, 34(3): 1065-1087, DOI: 10.16951/atauniiibd.717441 \\
\hline
\end{tabular}

Öz: Çalışma tüketicisiyle benlik uyumuna sahip markaların marka aşkına ve marka aşkının da tüketicilerin davranışlarına (sadakat, pozitif ağızdan ağıza iletișim) olan etkisinin belirlenmesi amacıyla hazırlanmıştır. Böylelikle tatmin yaşayan tüketicilerin markalar hakkındaki duygularının daha incelikli bir görünümü ortaya konulmak istenmiștir. Araștırmanın evrenini paketlenmiş ürünler (alkolsüz içecekler, sabun, tahıl vs.) kategorisinde yer alan ve her bir ürün kategorisinde bu markayı kullanan tüketiciler oluşturmaktadır. Araştırmada hipotezlerin test edilmesi için Smart PLS 3 (Partial Least Squares) istatistik programı kullanılmıştır. Araştırmada ölçülmesi amaçlanan hipotezlerin testi için bootstrapping tekniği uygulanmıştır. Analiz sonuçlarına göre benlik ifade eden markanın, marka aşkı ve pozitif ağızdan ağıza iletişimi pozitif yönde anlamlı olarak etkilediği ayrıca marka aşkı değişkeninin marka sadakati ve pozitif ağızdan ağıza iletişimi pozitif etkilediği belirlenmiștir. Bir bașka değișken olan marka sadakatinin pozitif ağızdan ağıza iletişimi benzer bir şekilde pozitif ve anlamlı bir şekilde etkilediği tespit edilmiştir. Anahtar Kelimeler: Benlik İfade Eden Marka, Marka Aşkı, Marka Sadakati, Pozitif Ağızdan Ağıza İletişim

An Investigation of The Relationship between Self-Expressive Brand, Brand Love, Positive Word- of Mouth and Brand Loyalty: A Research in Packaged Product Category

Abstract: The study was prepared to determine the effect of brands that have selfharmony with consumers on brand love and also brand love on consumers' behavior (loyalty, positive word of mouth communication). In this way, it is aimed to reveal a more subtle appearance of satisfied consumers' feelings about brands The universe of the research is consumers who are in the category of packaged products (soft drinks, soap, cereal, etc.) and who use this brand in each product category. In order to test the hypotheses, Smart PLS 3 (Partial Least Squares) statistics program was used in the research. Bootstrapping technique was applied to test the hypotheses that are aimed to be measured in the research. According to the results of the analysis, it has been determined that the self-expressive brand positively affects brand love and positive word-of mouth, and the brand love variable positively affects brand loyalty and positive word-of mouth. Another variable, brand loyalty has been found to positively and significantly affect positive word-of-mouth.

Keywords: Self-Expressive Brand, Brand Love, Brand Loyalty, Positive Word-Of Mouth.

${ }^{1}$ Öğr. Gör. Dr., Bingöl Üniversitesi, Sosyal Bilimler MYO, Yönetim ve Organizasyon Bölümü, https://orcid.org/0000-0001-9365-8677

${ }^{2}$ Dr. Öğr. Üyesi, Gaziantep Üniversitesi, Ŏguzeli MYO, Mülkiyeti Koruma ve Güvenlik Bölümü, https://orcid.org/0000-0002-8718-1822 
Benlik Ifade Eden Marka, Marka Aşkl, Pozitif Ă̆ızdan Ăğza İletişim ve Marka Sadakati Arasindaki IIlişkinin İncelenmesi: Paketlenmiş Ürün Kategorisinde Bir Araştırma

\section{EXTENDED SUMMARY}

\section{Research Problem}

Based on the information in the literature, this study focused on the effect of the self-expressive brand, which is one of the variables accepted as the precursor of brand love, on brand love and the results of brand love (brand loyalty and positive word of mouth). It is also aimed to examine the effect of self-expressive brand and brand loyalty on positive word of mouth.

\section{Research Questions}

Does the self-expressive brand has a positive effect on brand love?

Are satisfied consumers who feel more brand love, show more loyalty?

Are satisfied consumers who feel more brand love show more positive word of mouth?

Does brand loyalty have a positive effect on positive word of mouth ?

Does the self-expressive brand has a positive effect on positive word of mouth?

\section{LiteratureReview}

This study, which examines the effect of satisfied consumers' brand love on the behavior of the brand, presents a concept ranging from satisfaction to brand love in line with the previous studies on the concept of brand love. Because researchers such as Carroll and Ahuvia (2006) and Fournier and Mick (1999) argue that brand love is an extension of satisfaction (emotional pleasures). This approach involves more than just satisfaction when the consumer expectations for the brand are met. Sternberg (1986) and Fisher (2006) presented a comprehensive approach that includes passion, loyalty and romance in their evaluations of the concept of interpersonal love, and subsequent consumer research has developed a concept ranging from satisfaction to brand love.

\section{Methodology}

The universe of the research is consumers who are in the category of packaged products (soft drinks, soap, cereal, etc.) and use this brand in each product category. Within the scope of the research convenience sampling method was applied, which is one of the non-random samples. The number of samples was evaluated based on the data in the 420 questionnaire forms.

Smart PLS 3 (PartialLeastSquares) statistics program was used to test the hypotheses in the research. To determine the validity of the research model, structure, discrimination and compliance validities were examined. The square root of AVE values was calculated to determine the discrimination validity (Fornell and Larcker, 1981). The Convergence Validity (AVE) and Composite Reliability (CR) values were examined to determine compliance validity. Confirmatory factor analysis (CFA) was calculated to determine the construct validity. 


\section{Results and Conclusions}

Path analysis was conducted to test the research model. When the path analysis results were examined, it was determined that the self-expressive brand, which is the independent variable, positively and significantly affects brand love and positive word-of mouth and the brand love variable positively affects brand loyalty and positive word-of mouth. Path analysis was conducted to test the research model. When the road analysis results were examined, it was determined that the brand, which expresses the self, which is the independent variable, positively affects brand love and positive mouth-to-mouth communication, and the brand love variable positively affects brand loyalty and positive mouth-to-mouth communication. Another variable, brand loyalty, has been found to positively affect the positive word-of mouth in a similar way. In this context, $\mathrm{H}_{1}, \mathrm{H}_{2}, \mathrm{H}_{3}, \mathrm{H}_{4}$ and $\mathrm{H}_{5}$ hypotheses were accepted.

In the study, it was concluded that self-expressive brand which is accepted as the premise of brand love, has a positive effect on brand love. This result includes consistency to the studies in the literature regarding the selfexpressive brand and the connection of the self concept have a positive effect on brand love (Carroll and Ahuvia, 2006; Hwang and Kandampully, 2012). Considering the other results obtained in the study, satisfied consumers' brand love, who feel more brand love, show more loyalty and positive word of. There are extensive studies in the literature that extend consumer satisfaction towards brand love (Fournier and Mick, 1999; Shimp and Madden, 1988; Ahuvia, 1993; Carroll and Ahuvia, 2006). Another result obtained in the study is that selfexpressive brand has a positive effect on positive word-of mouth. This result is consistent with the studies in the literature (Wallace et al., 2014; Ruane and Wallace, 2015; Aziz and Ngah, 2019). Finally, it was concluded that brand loyalty had a positive effect on positive word of mouth. This result includes consistency with the studies in the literature (Bilgin, 2017; Carpenter and Fairhurst, 2005).

The study has produced significant results for both practitioners and marketing researchers. First of all, the study proposed a comprehensive structure for brand love in line with previous studies, and the verification of all the hypotheses identified strengthened the proposed structure (within the scope of the determined variables) in the study of reference for brand love (Carroll and Ahuvia, 2006). This result produced information about the validity and improvement of the previous structure for brand love in marketing research.In addition, focusing on satisfied consumers' brand love has brought a more comprehensive perspective to the concept of brand love, reinforcing the structure from satisfaction to brand love. The study also produced results for practitioners. The fact that the interaction with self-expressive brands, as the predecessor of brand love, affects brand love and positive word of mouth reveals the necessity of understanding the identity elements of consumers in the 
Benlik Ifade Eden Marka, Marka Aşkl, Pozitif Ağızdan Ağıza Illetissim ve Marka Sadakati Arasindaki Ilișkinin İncelenmesi: Paketlenmiș Ürün Kategorisinde Bir Arașttrma

target market of businesses and developing appropriate brand strategies. In this way, it will be possible to create a strong love for the brand.

\section{Giriş}

Günümüzde tüketiciler markalardan değişik gerekçelerle yararlanmaktadırlar. Bazı tüketiciler için markalar, bir ürünü diğerlerinden ayırt etmeye yarayan klasik işlevinin dışında duygulara yön veren güçlü bir araç niteliğindedir. Örneğin Fournier (1998), tüketicilerin benlik ihtiyacını karşılayan markalara yöneldiklerinde duygusal tatmin yaşayacaklarını ifade etmektedir. Bu nedenle markalar, kendilerini ifade etme işlevlerinin bir parçası olarak, insanların anlamlı, değerli gördükleri ve hayatlarında iyi şeyleri hak ettiklerini ifade etmelerine izin veren duygusal tetikleyicilerdir. Bir başka deyişle, markalı ürün kullanımı, insanların içsel değere ilişkin duygularını dış dünyaya iletmelerinde güçlü bir arac1lık işlevine sahiptir (Shachar vd.,2010: 4). Tüketiciler kendi benliğini, kimliğini yansıtan markalardan daha fazla yararlanma eğiliminde olmaktadır.

Tüketiciler, benlik ifade eden markalara yönelik beğeni ve kullanımdan ziyade çok daha güçlü duygusal bağlar (marka aşkı) yaşayabilmektedir. Kişilerarası aşk literatürü zamanla tüketici araştırmalarına da yansımıştır. Tüketici araştırmalarında Shimp ve Madden (1988), Sternberg (1986)'in üçgen kişilerarası aşk teorisini psikolojiden tüketici literatürüne uyarlamış ardından Batra vd. (2012), marka aşkına yönelik teori ve uygulamaların kişilerarası aşk kavramına yönelik öğretilerle uyumlaştırılması gerektiğini savunarak iki nitel çalışmayla marka aşkı hakkında tüketici literatürüne önemli bilgiler kazandırmıştır. Carrol ve Ahuvia (2006) tüketici literatüründeki tatmin kavramını marka aşkı oluşturmanın öncülü olarak değerlendirmiştir. Carroll ve Ahuvia marka aşkını, tatmin olmuş bir müşterinin belirli bir markaya yönelik heyecan ve bağl1lığı olarak ifade etmişlerdir. Markaya yöneltilmiş aşk, tatmin olmuş tüketicilerin deneyimlerinin bir ifadesidir. Carroll ve Ahuvia, marka aşkını tatmin sonrası bir markaya yönelik derin bağlılık olarak ifade etmişler ve tatminden marka aşkına uzanan bütünsel yapıyı vurgulamışlardır. Bu çalışmada marka aşk1, tatmin olmuş tüketicilerin duygusal yönünü ifade etmektedir.

Tatmin olmuş tüketicilerin marka aşkının tüketici davranışlarını etkileyeceği açıktır. Zira tüketici güçlü duygusal bağlara sahip olduğu markaları gelecekte yeniden tercih edecek ve marka hakkında çevresindekilere olumlu söylemlerde bulunacaklardır. Gerçekleştirilen çalışmalar marka aşkının tüketicilerin davranışsal niyetlerini (sadakat, pozitif ağızdan ağıza iletişim vs.) olumlu yönde etkilediğini göstermiştir (Niyomsart ve Khamwon, 2016; Chaudhary, 2018).

$\mathrm{Bu}$ çalışmada literatürde yer alan bilgilere dayanarak, marka aşkının öncülü olarak kabul edilen değişkenlerden birisi olan benlik ifade eden markanın marka aşkına olan etkisine ve marka aşkının sonuçlarına (marka sadakatine ve pozitif ağızdan ağıza iletişime) odaklanılmıştır. Ayrıca, benlik 
ifade eden markanın ve marka sadakatinin pozitif ağızdan ağıza iletişime olan etkisinin de incelenmesi amaçlanmıştır. Böylelikle, tatmin olmuş marka aşkına sahip tüketicilerin tercih edilen markaya yönelik davranışlarının anlaşılması ve tahmini kolaylaşacaktır.

\section{Kavramsal Çerçeve}

\subsection{Markanin Benlik Ifade Etme Fonksiyonu}

Markalar, tüketicilerin kimliklerini ve yaşam tarzlarını ifade etmek için yararlandıkları önemli bir araç olarak görülmektedir (Cătălin ve Andreea, 2014: 104). Tüketiciler, markalardan değişik gerekçelerle yararlanmak arzusundadırlar. Bazı tüketiciler, markaları kendini ifade etmek bazıları ise sosyalleşmek ya da başkalarının beğenisini kazanmak amacıyla markalara yönelim göstermektedirler (Czellar vd., 2010: 4). Vries vd. (2017), tüketicileri markalarla ilişki kurmaya motive eden nedenleri; kendini ifade etme, sosyalleşme, bilgi edinme güdüsü ve bilgi olarak sıralamaktadır (Vries, 2017: 9). Tüketici davranışları literatüründe de tüketicilerin içsel değerlerini, kimliklerini ve öz-imajı ifade etmek için markalardan ve ürünlerden sıklıkla yararlandıkları rapor edilmektedir (Cătălin ve Andreea, 2014; Ilaw, 2014). Buna göre tüketiciler, "kendini ifade etmek" veya markanın "duygusal faydalarını yaşamak" için markalara yönelirler (Phau ve Lau, 2000: 428). Diğer taraftan tüketiciler, kendi imajlarını oluşturmak, ifade etmek ve geliştirmek için tüketime yöneldiklerinde benlik uyumunun tüketici davranışı üzerindeki etkisi çoğunlukla sembolik veya kendini ifade eden ürün özellikleri tarafından yönlendirilen değer-açıklayıcı tüketim faaliyetlerinde belirgindir (Mazodier ve Merunka, 2014: 1553).

Bazı markalar, tüketicilere basit fayda unsurlarından ziyade güçlü değer bağlantıları sunmaktadır (Ruane ve Wallace, 2015: 336). Bu kapsamda içsel kimliği ifade eden markalar sembolik anlamlara sahip olup, bireyleri tüketime yönlendiren esas faktör, işlevsel yarardan ziyade ürünün kişisel ve sosyal anlamlarında saklıdır (Steinhart vd., 2014: 474). Fournier (1998), tüketicilerin benlik ihtiyacını karşılayan markalara yöneldiklerinde, duygusal tatmin yaşayacaklarını ifade etmektedir. Bu yüzden markalar, kendilerini ifade etme işlevlerinin bir parçası olarak, insanların anlamlı, değerli gördükleri ve hayatlarında iyi şeyleri hak ettiklerini ifade etmelerine izin vermektedir. Diğer bir ifadeyle, markalı ürün kullanımı, insanların içsel değere ilişkin güçlü duygularını diş dünyaya iletmelerinde güçlü bir aracılık işlevi görmektedir (Shachar vd., 2010: 4). Markalı ürünlere yönelimlerde tüketici tutumları büyük öneme sahiptir. Örneğin tüketiciler, kendi kimliğini ifade eden markaları deneyimlediklerinde ya da bu markalara ilişkin olumlu tutuma sahip olduklarında daha fazla olumlu iletişim davranışı sergilemektedirler (Wallace vd., 2014). Ayrıca marka kişiliğinin tüketici öz-değerleriyle uyumlu olması da önemlidir. Markalardan, kendi öz-kimliklerini ifade etmek için yararlanan tüketiciler, kendi benliklerini ve kişiliklerini açıklamak için markanın sahip 
Benlik Ifade Eden Marka, Marka Aşkl, Pozitif Ağızdan Ağıza Illetissim ve Marka Sadakati Arasindaki Ilișkinin İncelenmesi: Paketlenmiș Ürün Kategorisinde Bir Arașttrma

olduğu kişilik özelliklerinden fazlaca etkilenmektedirler (Phau ve Lau, 2000: 430).

\subsection{Aşk ve Marka Aşkı Kavramı}

Sternberg (1986)'in ünlü “Aşk Teorisi'nin Bileşenleri” çalışmasında aşk kavramı "kısmen genetik olarak iletilen içgüdülerden ve itici güçlerden türetilmiş gibi görünen karmaşık bir bütünlük" olarak tanımlanmıştır. Aşk kavramına ilişkin psikolojik değerlendirmeler içeren bu çalışma, kavramı; bir üçgenin üç köşesini oluşturan ve birbirini tamamlayan duygular olarak nitelendirmiştir. $\mathrm{Bu}$ üç bileşen; yakınlık (üçgenin üst tepe noktası), tutku (üçgenin sol tepe noktası) ve karar/bağlılıktır (üçgenin sağ tepe noktası). Teoriye göre bu üç kesişim noktası birbirini tamamlayan aşkın ayrılmaz parçalarıdır (Sternberg, 1986: 119). Aşk, romantizm içeren duygu, motivasyon ve davranışlardan oluşmaktadır (Fisher, 2006: 88). Önceleri sadece kişilerarası ya da nesneye yöneltilmiş duyguları içeren kavram zamanla tüketici literatüründe de kendisine yer bulmuştur. Tüketici araştırmalarında Shimp ve Madden (1988), Sternberg (1986)'in üçgen kişilerarası aşk teorisini, psikolojiden tüketici literatürüne uyarlamış ardından Ahuvia (1993) konuya ilişkin bilinen ilk ampirik çalışmayı gerçekleştirmiştir. Ancak her iki araştırmacı da marka aşkının (ticari ürünlere yöneltilmesi nedeniyle) kişilerarası aşk formlarıyla tam olarak benzer olmayacağını ifade etmişlerdir. Daha sonraları Batra vd. (2012), aşk kavramının psikoloji literatüründe çoğu zaman romantizm, șefkat, özgecilik özelinde kişilerarası ilișkileri yansıttığını bu yüzden marka aşkına yönelik teori ve uygulamaların, kişilerarası aşk literatürüyle bağlantılarının sağlanması gerektiğini savunarak iki nitel çalışmayla marka aşkı hakkında tüketici literatürüne önemli bilgiler kazandırmışlardır. Bu çalışma önceki çalışmalar da (Shimp ve Madden, 1988; Ahuvia, 1993; Carroll ve Ahuvia, 2006) ifade edilen "kişilerarası aşk-ticari ürüne yöneltilmiş aşk" arasındaki uyumsuzluğa ilişkin kaygıları biraz daha azaltarak kişilerarası aşk formlarını tüketici literatürüne daha fazla entegre etmiştir.

Marka aşkı, hem pazarlamacılar hem de tüketiciler için oldukça önemlidir (Shimp ve Madden, 1988; Ahuvia, 1993; Bagozzi vd., 2017). Markayla kurulan güçlü bağlar ve hissedilen güçlü duygular markaya yöneltilmiş aşk1 ifade etmektedir (Unal ve Aydın, 2013: 77). Marka aşk1; tüketicilerin markaya olan sevgisini, tutkusunu, bağlılı̆̆ını, olumlu değerlendirmelerini kısacası duygularını ifade etmektedir (Kang, 2015: 91). Marka aşkı esasında tüketici ile marka arasındaki güçlü ilişkiyi yansıtmaktadır. Tüketicilerin yararlandıkları markayla ilişki sürecinde yaşadığı olumlu deneyimler (mesela güven) veya marka özellikleri (marka kalitesi, hedonik özellikler vs.) marka aşkı oluşmasına doğrudan etki etmektedir (Albert ve Merunka, 2013: 258). Marka aşkı bulunun tüketiciler, zamanlarının önemli bir bölümünü ve enerjilerini duygusal bağlılık yaşadıkları markalarla geçirmek eğilimindedirler. Literatürde marka aşkının, tatminin (duygusal hazların) bir uzantısı olduğunu savunan çalışmalar yer 
almaktadır (Carroll ve Ahuvia, 2006; Fournier ve Mick, 1999). Tatmin, marka aşkı oluşturmanın temelidir (Pandowo, 2016: 81). Carroll ve Ahuvia (2006: 81) marka aşkını, tatmin olmuş bir müşterinin belirli bir markaya yönelik heyecan ve bağlılığı olarak ifade etmişlerdir. Markaya yöneltilmiş aşk, tatmin olmuş tüketicilerin deneyimlerinin bir ifadesidir. Carroll ve Ahuvia, marka aşkını tatmin sonrası bir markaya yönelik derin bağl1lık olarak ifade etmişler ise de Fournier ve Mick (1999) çalışmasındaki tatmine ilişkin kavramsal değerlendirmelerden yola çıkarak marka aşkı ve tatmin arasındaki derin farklılıkları da ifade etmişlerdir. Çalışmalarında tatmin olmuş tüketicilerin belirli bir markaya olan aşk duygularını değerlendirmek için yeni bir yapı önermişlerdir. Buna göre marka aşkı, tatminden çok daha ötede duygusal bir bağl1lı̆̆ 1 ifade etmektedir. Ayrıca her iki kavram arasındaki farklılıklar da belirtilmiştir. Buna göre marka aşkı daha makro bir çerçeveye sahipken, tatmin daha dar bir ifadeyi temsil etmektedir. Ayrıca, tatmin genellikle bilişsel bir yargı olarak kavramsallaştırılırken, marka aşk1 çok daha güçlü bir duygusal odaklamayı yansıtmaktadır. Tatmin, işleme özgüdür ancak aşk marka ile uzun vadeli ilişkilerin sonucudur. Tatmin, beklentilerin onaylanmaması paradigması ile bağlantılıdır oysaki marka aşkı onaylama ya da beklenti teorilerini içermez. Son olarak marka aşkı, duyguları ifade etme istekliliğini (örneğin; "Bu markayı seviyorum!") ve tüketici kimlik entegrasyonunu içerirken; tatmin için her iki durum da zorunluluk içermemektedir (Fournier ve Mick, 1999; Carroll ve Ahuvia, 2006: 81). Kang (2015: 91), marka aşkının, tatminden daha fazla duygusallık içerdiğini belirtmektedir. Ayrıca tatmin, marka aşkı konseptini açıklamada tek başına güçlü bir açıklama sun(a)mamaktadır (Jones ve Sasser, 1995; Carroll ve Ahuvia, 2006; Konadu, 2018). Fournier (1998), çok yönlü tatmin modunun, hazzın ötesinde tüketicinin ürünle yakın, yüksek ve kaliteli bir ilişkiye ulaştığı noktayı yansıttığını belirtmektedir. $\mathrm{Bu}$ nedenle güçlü davranışsal, duygusal ve psikolojik öngörü tatminin-aşka uzanan yapısını yani yoğun ve derin tatmin boyutunu yansitmaktadır (Fournier ve Mick, 1999: 11). $\mathrm{Bu}$ değerlendirmeler ışığında bu çalışmada da marka aşkı kavramsal ve kuramsal olarak "tatmin olmuş müşterilerin marka aşkı" olarak değerlendirilmiştir.

\subsection{Marka Sadakati}

Marka sadakati, tercih edilen bir mal veya hizmeti gelecekte yeniden satın alma veya bu niyeti koruma konusunda derin bir bağl1lıktır (Oliver, 1997). Başka bir deyişle, sadakat, bir mal veya hizmet satın almak için gelecekteki davranış taahhüdü veya diğer alternatiflerin mümkün olduğu her durumda bir işletme ile bağlantı olarak görülebilir (Kement ve Çavuşoğlu, 2017). Backman ve Crompton (1991: 217), sadakatin iki boyutu; psikolojik bağlanma (olumlu tutum) ve davranışsal tutarlılı̆̆ın birlikte oluştuğunda gerçek bir sadakat oluşacağını ileri sürmektedirler. Glasman ve Albarracın (2006), tutum ile davranış arasındaki ilişkiyi incelemiş, tutumun gelecekteki davranışlarla ilişkili 
Benlik Ifade Eden Marka, Marka Aşkl, Pozitif Ağgzdan Ağıza İletissim ve Marka Sadakati Arasindaki Ilișkinin İncelenmesi: Paketlenmiș Ürün Kategorisinde Bir Arașttrma

olduğunu tespit etmişlerdir. Bir markaya yönelik müşteri sadakati, mal ve hizmetlerin satın alınması suretiyle tercih edilen işletmeye yönelik ilişkinin sürdürülmesidir (Behara vd., 2002). Jacoby ve Kyner (1973: 2-3) müşteri sadakatini, "zaman içinde bir dizi marka dışında bir veya daha fazla alternatif markaya ve psikolojik süreçlerin bir fonksiyonu olan karar verme birimi tarafindan ifade edilen davranışsal tepki" olarak ifade etmektedirler. Oliver (1997)'ın müşteri sadakatinin tutum boyutuna ilişkin hiyerarşik düzeni, tutum sadakatinin çok boyutlu yapısını ortaya koymaktadır. Buna göre müşteri sadakatinin tutum boyutları; bilişsel (cognitive), duygusal (affective) ve çabasal (conative) ve nihayetinde davranışsal/eylemsel (behavioural) olarak kategorize edilmiştir. Bilişsel sadakat, müşteri sadakatinin ilk aşamasıdır ve ürün bilgisine dayanır. Bu aşamada müşteri değeri ön plandadır ve daha güçlü değer sunan alternatifler, müşteri sadakatinin yönünü etkileyebilir (Evanschitzky ve Wunderlich, 2006: 331-332). Duygusal sadakat aşaması, bilişsel boyutun müşteri zihninde bıraktığı olumlu kanının duygusal bir boyuta dönüşmesidir (Han vd., 2008: 24). Çabasal aşama ise çoğunlukla eylemle sonuçlanan davranışsal niyetleri ifade etmektedir (Radder ve Han, 2013: 1262). Davranışsal boyut ise eylemin gerçekleştiği son sadakat aşamasını belirtmektedir. Bilişsel, duygusal ve çabasal sadakat aşamaları esasen tüketici içsel zihinsel süreci ile ilgilidir ve kendini dışa vurmaya eğilimli değildir. Öte yandan, davranışsal sadakat daha dışsal olarak sadakat eylemlerinin dışsal yönünü vurgulamaktadır (Demirağ ve Durmaz, 2019). Day (1969), müşterilerin tercih ettikleri markaya yönelik olumlu tutuma sahip olduklarında markaya yönelik tekrarlı satın alma eylemine (davranışa) yöneleceklerini belirtmiş, tutum ve davranış arasındaki bağıntıya dikkat çekmiştir. Böylelikle müşteri sadakatinin hem "tutum" hem de "davranış" olarak birlikte değerlendirilmesi gerektiği konusunda salt "davranışa" odaklanan önceki çalışmaları (Cunningham, 1961; Harary ve Lipstein, 1962) genişletmiş, daha sonraki çok boyutlu çalışmaların da önünü açmıştır. Buna göre markaya yönelik güçlü bir tutum (düşük satın alma oranı) gizli sadakati; güçlü bir satın alma davranışı (düşük bir tutum) sahte sadakati; güçlü bir tutum ve davranışın eşanlı olması ise gerçek sadakati yansıtmaktadır (Day, 1969; Demirăg ve Durmaz, 2020).



Pozitif ağızdan ağıza iletişim, bir şirkete ait mal ve hizmetlere ilişkin bilgilerin, şirketin reklam gibi tutundurma çabaları içermeksizin, insanlar arasında doğrudan yayılmasını ifade etmektedir (Maisam ve Mahsa, 2016: 20). $\mathrm{Bu}$ durum tüketicinin dışsal değişkenlerden bağımsız özgür iradesini yansıtan sosyal bir davranıştır (Ferguson vd., 2009: 26). Tüketiciler, ürün tüketimi sonrasında tüketim deneyimlerine ilişkin yanıt oluştururlar. Bilgi alışverişine bağlı olarak deneyim oluşturan faktörler tüketicide tatmin yaratırsa farklı iletişim araçları kullanılarak pozitif iletişim ortaya çıkarır (Taylor vd., 2012). Maisam ve Mahsa (2016) pozitif ağızdan ağıza iletişimin tüketici üzerindeki 
etkisini bilgi kaynaklarına dayandırmaktadır. Buna göre tüketiciler, reklam vs. yollarla edindikleri bilgilerden ziyade doğrudan (birincil kaynaklardan) elde ettikleri bilgilere daha fazla güvendiklerinden ürüne yönelik güçlü davranışsal niyetler geliştirirler. Diğer ifadeyle birincil referans kaynakları olarak görülen (iş, aile vs.) etkileyiciler, tüketicileri ürün ya da markaya yönelik tutum ve davranış geliştirmeye yönlendirmektedir (Maisam ve Mahsa, 2016: 20). Aile ve arkadaş gruplarıyla gerçekleştirilen ağızdan ağıza iletişim, özel davranışlar sergilemeyi kolaylaştırmaktadır. Zira tüketiciler yakın çevresinin deneyimlerine daha fazla eğilim gösterirler (Yasvari vd., 2012: 229). Oliver (1997), tüketicileri pozitif iletişime yönlendiren temel motivasyonu tatmine dayandırdığından, tatmin yaratan haz (zevk) öğelerine odaklanılmasını tavsiye etmektedir. Rasyonel bir tüketicinin deneyimlediği ve haz almadığ tavsiye etmesi olanaklı değildir. Benzer şekilde Saha ve Theingi (2009), deneyim sonrası yaşanan tatminin tüketicilerin pozitif iletişiminde süreklilik oluşturacağını savunmaktadırlar. Ağızdan ağıza iletişimin algıları ve eylemleri etkileme potansiyelinin, gönderen-alıcı ilişkisinin doğasına, mesajın zenginliği, gücüne, iletilmesine, çeşitli kişisel ve durumsal faktörlere bağlı olduğunu belirtmektedirler (Sweeney vd., 2008). Casielles vd. (2013), ağızdan ağıza iletişimin etkinlik ve değer olmak üzere iki boyuta sahip olduğunu ifade etmektedirler. Buna göre etkinlik; iletişimin ne sıklıkla gerçekleştirildiği, göndericinin iletişim kurduğu kişi sayısı ve sağlanan bilgi miktarını içermektedir. Değer ise pozitif, negatif veya nötr olabilir (Casielles vd., 2013: 44). Günümüzde iletişim teknolojilerinde yaşanan gelişmeler, internetin yaygınlaşması, tüketicilerin teknoloji kullanma yeterliliklerinin artması vs. ürün/markaya yönelik her türlü deneyim ve görüşlerin elektronik ortamda paylaşılması eğilim ve davranışını güçlendirmektedir. Bloglar, bilgi alış-veriş siteleri, sosyal medya (Instagram, Path ve Twitter) uygulamalar1; resimleri, fikirleri ve önerileri toplumun daha geniş bir alanına paylaşmak için daha uygun bir yol sunmaktadır (Purnasari ve Yuliando, 2015: 150). Daha az iletişim çabasıyla daha fazla kişiye ulaşabilme kolaylığı tüketicileri bu davranışa yönlendiren temel motivasyon olarak değerlendirilebilir. Ağızdan ağıza iletişim, reklam gibi tek yönlü etkiler oluşturmamaktadır. Gönderenin iletileri ve alıcının reaksiyonları, iletişimi karşılıklı bir diyalog sürecine yönlendirmektedir. $\mathrm{Bu}$ kapsamda iletişimin gücü; göndericinin ve alıcı arasındaki iletişimin etkinliğine (soru-cevap paylaşımlarına) ve sonuçların takibine bağlıdır (Wilklie, 1990). İnternet ortamında gerçekleştirilen iletişim bu yüzden çok değerlidir. Zira, gönderen ve alıcı arasında herhangi bir aracı bulunmadığından ve çevrimiçi iletişim kanalları aktif olduğundan her türlü ağızdan ağıza iletişimin etkinliğini değerlendirmek daha olanaklı olmaktadır. 
Benlik Ifade Eden Marka, Marka Aşkl, Pozitif Ă̆ızdan Ăğza İletişim ve Marka Sadakati Arasındaki İlişkinin Incelenmesi: Paketlenmiş Ürün Kategorisinde Bir Araştırma

\section{Kuramsal Çerçeve}

\subsection{Benlik Ifade Eden Marka ve Marka Aşkı}

Tüketiciler, "kendini ifade etmek" veya markanın "duygusal faydalarını yaşamak" için markalara yönelirler (Phau ve Lau, 2000: 428). Aron ve meslektaşları (Aron ve Aron, 1985; Aron vd., 1995) kişilerarası aşk1, kişilerarası duyguların buluşması olarak nitelendirmiş ve aşkın, kişinin benlik duygularını etkilediğini ifade etmişlerdir. Benliği ifade eden markaların ve benlik konsepti bağlantısının marka aşkı üzerinde pozitif etkisi olduğuna ilişkin literatürde çalışmalara rastlanılmaktadır (Carroll ve Ahuvia, 2006; Hwang ve Kandampully, 2012). Erciş vd. (2018) 300 katılımcidan toplanan verilerle gerçekleştirmiş oldukları çalışmalarında, benlik-marka bağının marka sadakati üzerindeki etkisinde, marka aşkı ve marka deneyiminin aracılık rolleri olduğu sonucuna ulaşmışlardır. Wallace vd. (2014), bir markaya ilişkin sevgi hisseden Facebook kullanıcılarına ilişkin yapılan çalışmada, "sevilen" markaların kendini ifade eden doğası ile marka aşk1 arasında pozitif bir ilişki tespit etmişlerdir. Karjaluoto vd. (2016), 342 tüketiciyle gerçekleştirmiş oldukları çalışmalarında, tüketicilerin benlik duygularını yansıtan markalarla kurdukları iletişimin ve güvenin marka aşkı ile güçlü bir ilişkiye sahip olduğunu tespit etmişlerdir. Chaudhary (2018), marka aşkına yönelik gerçekleştirmiş olduğu çalışmasında, marka aşkının, benliği ifade eden marka kullanımlarından pozitif ve doğrudan etkilendiğini tespit etmiştir.

$\mathrm{Bu}$ bilgilere dayanarak aşağıdaki hipotez geliştirilmiştir:

$H_{1}$ : Benliği ifade eden markanın, marka aşkı üzerinde pozitif etkisi vardir.

\subsection{Marka Aşkl, Marka Sadakati ve Pozitif Ağızdan Ă̆ıza İletişim}

Niyomsart ve Khamwon (2016) gerçekleştirmiş oldukları çalışmalarında marka aşkının, marka sadakatini ve pozitif ağızdan ağıza iletişimi pozitif yönde etkilediği sonucuna ulaşmışlardır. Literatürde müşteri tatmini ve marka aşkı arasındaki ilişkilere yönelik çalışmalara rastlanılmakla birlikte (Song vd., 2019) tatmine ilişkin marka aşkı yaşayan tüketicilerin marka aşklarının, marka sadakati ve ağızdan ağıza iletişime olan etkisinin incelendiği sınırlı sayıda çalışma tespit edilmiştir (Carroll ve Ahuvia, 2006; Chaudhary, 2018). Literatürde, tüketici tatminini marka aşkına doğru genişleten kapsamlı çalışmalar yer almaktadır (Fournier ve Mick, 1999; Shimp ve Madden, 1988; Ahuvia, 1993; Carroll ve Ahuvia, 2006). Bu çalışmalara ve pozitif ağızdan ağıza iletişim, sadakat literatürüne dayanarak, tatmin olmuş tüketicilerin marka aşkı hakkındaki bilgilerin, tüketim sonrası davranışlarının hem anlaşılmasını hem de öngörülmesini arttıracağına inanılmaktadır. Ayrıca tatmin olmuş marka aşkına sahip tüketicilerin daha fazla sadakat ve başkalarına karşı pozitif iletişime sahip olacakları düşünülmektedir. Carroll ve Ahuvia (2006), tatmin olmuş müşterilerin marka aşkının, olumlu ağızdan ağıza iletişimi ve marka sadakatini pozitif yönde etkilediği sonucuna ulaşmışlardır. Chaudhary (2018), 
marka sadakatinin ve pozitif ağızdan ağıza iletişimin hissedilen güçlü marka aşkından pozitif etkilendiği sonucuna ulaşmışlardır. Huang (2017), müşterinin davranışsal sadakatinin geliştirilmesinde marka aşkının kritik bir rol oynadığını ifade etmektedir. Sarkar ve Pradhan (2016), mağaza sadakat programlarının mağaza sadakati ve mağaza ilişkileri üzerindeki etkilerinin mağaza tatminimağaza aşkına nasıl aracılık edebileceğini araştırmış, sadakat programlarının mağaza sadakati ve mağaza ilişkileri üzerindeki etkisine hem mağaza tatmininin hem de mağaza aşkının aracılık ettiği sonucuna ulaşmışlardır. Loureiro vd. (2017) marka aşkının, çevrimiçi marka katılımı ve çevrimiçi ağızdan ağıza iletişim arasında aracılık etkisi olduğu sonucuna ulaşmışlardır. Karjaluoto vd. (2016), marka aşkının hem çevrimiçi hem çevrimdışı ağızdan ağıza iletişim üzerinde pozitif etkisi olduğu sonucuna ulaşmışlardır. Wallace vd. (2014), benliği ifade eden ve aşk duyulan markalarla ilişki geliştiren tüketicilerin, marka için pozitif ağızdan ağıza iletişim gerçekleştirme olasılıklarının daha yüksek olduğunu belirtmişlerdir. Algharabat (2017), marka aşkının marka sadakati üzerindeki pozitif etkisini ifade etmiştir. Bilgin (2017) restoran işletmeleri üzerine yapmış olduğu çalışmasında marka sadakatinin pozitif ağızdan ağıza iletişimi pozitif bir şekilde etkilediğini tespit etmiştir. Benze rbir şekilde Carpenter ve Fairhurst (2005) müşteri sadakati ve pozitif ağızdan ağıza iletişim arasında güçlü bir ilişki olduğunu belirtmişlerdir.

Bu bilgilere dayanarak aşağıdaki hipotezler geliştirilmiştir:

$\mathrm{H}_{2}$ : Marka aşkının marka sadakati üzerinde pozitif etkisi vardır.

$H_{3}$ : Marka aşkının pozitif ă̆ızdan ă̆ıza iletişim üzerinde pozitif etkisi vardir.

$H_{5}:$ Marka sadakatinin pozitif ăğzdan ăgıza iletişim üzerinde pozitif etkisi vardir.

\subsection{Benlik-Ifade Eden Marka ve Pozitif Ağızdan Ăğza İletişim}

Shachar vd. (2010), benliği-ifade eden markalardan yararlanan tüketicilerin, markalardan yararlanmak suretiyle; anlamlı, değerli gördükleri ve hayatlarında iyi şeyleri hak ettiklerine inandıkları düşüncelerini söylemlerine yansıttıklarını belirtmektedirler. Bu söylemler, olumlu duyguları yansıttığından büyük oranda pozitif mesajlar içermektedir. Wallace vd. (2014), benliği ifade eden markalarla etkileşime giren tüketicilerin bu markalar için daha fazla ağızdan ağıza iletişim sunacaklarını ifade etmiş̧lerdir. Aziz ve Ngah (2019), pozitif iletişimin yayılması için işletmelerin benliği-ifade eden markalara karşı etkin stratejiler geliştirmeleri gerektiğini vurgulamışlardır. Ruane ve Wallace (2015), 675 tüketici ile gerçekleştirmiş oldukları çalışmalarında; benliği-ifade eden markaları tercih eden tüketicilerin daha sadık ve ağızdan ağıza iletişim sergileme olasılıklarının daha yüksek olduğu sonucuna ulaşmışlardır. Carroll ve Ahuvia (2006), benliği-ifade eden markalarla pozitif ağızdan ağıza iletişim arasında anlamlı ve pozitif bir ilişki olduğu sonucuna ulaşmışlardır.

Bu bilgilere dayanarak aşağıdaki hipotez geliştirilmiştir: 
Benlik Ifade Eden Marka, Marka Aşkl, Pozitif Ă̆ızdan Ăğza İletişim ve Marka Sadakati Arasındaki İlişkinin Incelenmesi: Paketlenmiş Ürün Kategorisinde Bir Araştırma

$H_{4}:$ Benliği ifade eden markanın, pozitif ă̆ızdan ă̆ıza iletişim üzerinde pozitif etkisi vardır.

\section{Yöntem}

Çalışma benlik uyumuna sahip markaların marka aşkına ve marka aşkının tüketicilerin davranışlarına (sadakat, pozitif ağızdan ağıza iletişim) olan etkisinin incelenmesi amacıyla hazırlanmıştır. Tatmin yaşayan tüketicilerin markalar hakkındaki duygularının daha incelikli bir görünümünün ortaya konulması hedeflenmiştir. Araştırmanın evrenini Türkiye'de, paketlenmiş ürünler (alkolsüz içecekler, sabun, tahıl vs.) kategorisinde yer alan ve her bir ürün kategorisinde bu markayı kullanan, tüketiciler oluşturmaktadır. Araştırma kapsamında evreninin çok geniş olması nedeniyle tesadüfi olmayan örneklemelerden 'kolayda örneklem' yöntemi uygulanmıştır. Evreni temsil edebileceği göz önünde bulundurularak örneklem sayısı ise 420 anket formunda yer alan verilerden yola çıkarak değerlendirilmiştir.

Anket formu demografik sorular ve belirlenen modelin tespiti amaciyla ankete eklenen ölçek sorularından oluşmaktadır. İlk bölümde katılımcıların demografik özelliklerinin belirlenmesi amacıyla cinsiyet, yaş, eğitim, medeni durum ve gelir seviyesi soruları sorulmuştur. İkinci bölümde benlik ifade eden marka, marka aşkı, marka sadakati ve pozitif ağızdan ağıza iletişim soruları Carrol ve Ahuvia (2006)'nın çalışmalarından uyarlandığ 1 şekliyle kullanılmıştır. Kullanılan ifadeler beşli likert ölçeğine uyarlanarak "kesinlikle katılmıyorum, kesinlikle katılıyorum" (1-5) aralığında katılımcılara yöneltilmiştir.

Araştırmaya katılan bireylerin demografik özellikleri incelendiğinde; ankete katılanların 199'u erkek $(\% 47,4)$ ve 221 'i kadın $(\% 52,6)$ tüketicilerden oluşmaktadır. Katılımcıların \%42,4 ile 25-34 yaş aralığında yoğunlaştığı görülmektedir (n: 178). Katılanların medeni durumu incelendiğinde \%51,4'ünün (n: 216) evli olduğu tespit edilmiştir. Bireylerin eğitim durumları incelendiğinde \%39,8'inin (n:167) lisans düzeyinde eğitim aldığı ve gelir seviyesinin \%82,4 ile orta olduğu tespit edilmiştir (n: 346).

Tablo 1: Katılımcıların Demografik Özellikleri

\begin{tabular}{|c|c|c|c|}
\hline \multicolumn{2}{|c|}{ Demografik Değișkenler } & n & $\%$ \\
\hline \multirow{2}{*}{ Cinsiyet } & Erkek & 199 & 47,4 \\
\hline & Kadın & 221 & 52,6 \\
\hline \multirow{2}{*}{ Medeni Durumu } & Evli & 216 & 51,4 \\
\hline & Bekâr & 204 & 48,6 \\
\hline \multirow{7}{*}{ Yaş } & 18 den küçük & 14 & 3,3 \\
\hline & $18-24$ & 116 & 27,6 \\
\hline & $25-34$ & 178 & 42,4 \\
\hline & $35-44$ & 57 & 13,6 \\
\hline & $45-54$ & 44 & 10,5 \\
\hline & $55-64$ & 9 & 2,1 \\
\hline & 65 ve üzeri & 2 & 0,5 \\
\hline
\end{tabular}


Tablo 2 Devamı: Katılımcıların Demografik Özellikleri

\begin{tabular}{lllll}
\hline \multirow{4}{*}{ Ĕgitim } & İlköğretim & 18 & 4,3 \\
\cline { 2 - 4 } & Lise & 109 & 26,0 \\
\cline { 2 - 4 } & Ön lisans & 94 & 22,4 \\
\cline { 2 - 4 } & Lisans & 167 & 39,8 \\
\cline { 2 - 5 } Gelir Durumu & Lisans Üstü & 32 & 7,6 \\
\hline & Oüşk & 26 & 6,2 \\
\cline { 2 - 4 } & Orta & 346 & 82,4 \\
\cline { 2 - 5 } & Yüksek & 10 & 9,0 \\
\cline { 2 - 5 } & Çok yüksek & $\mathbf{4 2 0}$ & $\mathbf{1 0 0 , 0}$ \\
\hline
\end{tabular}

Araştırmada hipotezlerin test edilmesi için Smart PLS 3 (Partial Least Squares) istatistik programı kullanılmıştır. Ölçülmesi hedeflenen araştırma modeli şu şekildedir;

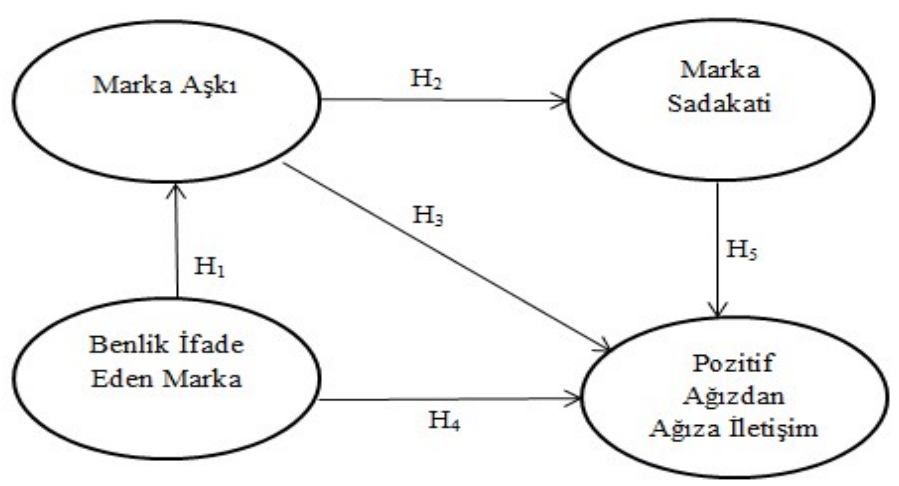

Şekil 1: Araştırma Model Önerisi

\subsection{Araştırma Modeli Geçerlilik ve Güvenilirlik Sonuçları}

Benlik ifade eden marka, marka aşkı, marka sadakati ve pozitif ağızdan ağıza iletişimin ayrım geçerliliği sonuçları Tablo 2 ve Tablo 3'te detaylı olarak gösterilmektedir.

Tablo 2: Ayrım Geçerliliği ve Tanımlayıcı İstatistikler

\begin{tabular}{|c|c|c|c|c|c|c|}
\hline Değişkenler & $\mathbf{X}$ & SD & 1 & 2 & 3 & 4 \\
\hline 1 Benlik İfade Eden Marka & 3,98 & ,722 & $\overline{0,804}$ & & & \\
\hline 2 Marka Aşk1 & 3,67 & ,694 & ,625 & 0,735 & & \\
\hline 3 Marka Sadakati & 3,75 &, 856 &, 553 & ,729 & 0,877 & \\
\hline 4 Pozitif Ağızdan Ağıza İletişim & 3,81 & 877 &, 570 &, 716 & ,788 & $\mathbf{0 , 8 8 5}$ \\
\hline
\end{tabular}

Araştırma modelinin geçerliliğini belirlemek için yapı, ayrım ve uyum geçerlilikleri incelenmiştir. Ayrım geçerliliğini belirlemek için AVE değerlerinin karekökü hesaplanmıştır (Fornell ve Larcker, 1981). Uyum geçerliliğini belirlemek için ortalama açıklanan varyans (AVE) ve bütünleşik 
Benlik Ifade Eden Marka, Marka Aşkı, Pozitif Ă̆ızdan Ă̆ıza İletişim ve Marka Sadakati Arasındaki İlişkinin Incelenmesi: Paketlenmiş Ürün Kategorisinde Bir Araştırma

güvenilirlik (CR) değerleri incelenmiştir. Yapı geçerliliğini belirlemek için ise doğrulayıcı faktör analizi (DFA) hesaplanmıştır. Geçerlilik ve güvenilirlik sonuçları Tablo 3'te detaylı olarak gösterilmektedir.

Tablo 3: Geçerlilik ve Güvenilirlik Sonuçlart

\begin{tabular}{|c|c|c|c|c|c|c|}
\hline & & & $\overline{\mathbf{C A}}$ & $\mathbf{C R}$ & AVE & DFA \\
\hline Değişkenler & $\mathbf{X}$ & S.S. & $\begin{array}{c}\geq \mathbf{, 6 0} \\
\text { Kalay } \\
\text { cl, } \\
2005\end{array}$ & $\begin{array}{c}\geq, \mathbf{7 0} \\
\text { Hair } \\
\text { vd., } \\
2012\end{array}$ & $\begin{array}{c}\geq \mathbf{5 0} \\
\text { Fornell } \\
\text { ve } \\
\text { Larcker, } \\
1981\end{array}$ & $\begin{array}{c}\geq \mathbf{7 0} \\
\text { Kaise } \\
r, \\
1974\end{array}$ \\
\hline \multicolumn{7}{|c|}{ Benlik İfade Eden Marka ( $\alpha:$ 0,92) } \\
\hline Benlik 1 & 4,27 & ,946 & \multirow{8}{*}{,92 } & \multirow{8}{*}{,93 } & \multirow{8}{*}{,64 } &, 817 \\
\hline Benlik 2 & 4,17 & ,964 & & & & ,799 \\
\hline Benlik 3 & 4,18 & ,972 & & & & ,800 \\
\hline Benlik 4 & 3,87 &, 840 & & & & ,829 \\
\hline Benlik 5 & 3,78 &, 891 & & & &, 790 \\
\hline Benlik 6 & 3,77 &, 889 & & & &, 835 \\
\hline Benlik 7 & 3,90 &, 858 & & & & ,774 \\
\hline Benlik 8 & 3,91 &, 829 & & & & ,782 \\
\hline \multicolumn{7}{|c|}{ 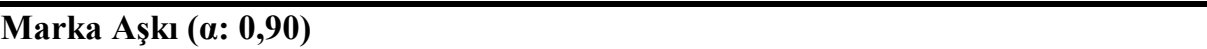 } \\
\hline Marka Ask 1 & 3,80 &, 841 & \multirow{10}{*}{,90 } & \multirow{10}{*}{,92 } & \multirow{10}{*}{, 54} & ,748 \\
\hline Marka Ask 2 & 3,76 & ,915 & & & & ,772 \\
\hline Marka Ask 3 & 3,77 &, 884 & & & & 714 \\
\hline Marka Ask 4 & 3,81 & ,954 & & & & ,782 \\
\hline Marka Ask 5 & 3,75 & ,906 & & & & ,748 \\
\hline Marka Ask 6 & 3,61 & ,958 & & & & ,770 \\
\hline Marka Ask 7 & 3,49 & 1,01 & & & & ,730 \\
\hline Marka Ask 8 & 3,54 & 1,00 & & & & ,712 \\
\hline Marka Ask 9 & 3,63 & 981 & & & & 672 \\
\hline Marka Ask 10 & 3,56 & ,975 & & & & ,698 \\
\hline \multicolumn{7}{|c|}{ Marka Sadakati $(\alpha: 0,89)$} \\
\hline Sadakat 1 & 3,75 & ,997 & \multirow{4}{*}{,90 } & \multirow{4}{*}{,93 } & \multirow{4}{*}{, 77} &, 872 \\
\hline Sadakat 2 & 3,75 & ,950 & & & & 913 \\
\hline Sadakat 3 & 3,72 & ,974 & & & & ,900 \\
\hline Sadakat 4 & 3,76 & ,985 & & & & 821 \\
\hline \multicolumn{7}{|c|}{ Pozitif Ağızdan Ağıza İletişim ( $\alpha:$ 0,90) } \\
\hline İletisim 1 & 3,92 & 1,02 & \multirow{4}{*}{90} & \multirow{4}{*}{,93 } & \multirow{4}{*}{, 78} & ,865 \\
\hline İletisim 2 & 3,79 & 1,02 & & & & 921 \\
\hline İletisim 3 & 3,81 & ,993 & & & & 913 \\
\hline İletisim 4 & 3,73 & ,919 & & & & ,839 \\
\hline
\end{tabular}

Uyum iyiliği değerleri benzer şekilde Smart PLS 3 (Partial Least Squares) istatistik programı ile incelenmiş elde edilen kriterler Tablo 3'te gösterilmiştir. 
Tablo 4: Model Uyum Indeksleri

\begin{tabular}{|c|c|c|c|}
\hline Kriter & $\chi^{2}$ & $\begin{array}{c}\text { NFI } \\
\geq, \mathbf{8 0} \\
\text { (Yaşlloğglu, 2017) }\end{array}$ & $\begin{array}{c}\text { SRMR } \\
\leq, \mathbf{0 8} \\
\text { (Hu ve Bentler, 1999) }\end{array}$ \\
\hline & 1720,410 & 0,80 & 0,065 \\
\hline
\end{tabular}

Elde edilen sonuçlara göre araştırma modelinin iyi bir uyum iyiliğine sahip olduğu tespit edilmiştir.

Ayrım geçerliliğini belirlemek için AVE değerlerinin karekökü hesaplanmıştır (Fornell ve Larcker, 1981). Fornell-Larcker kriterine göre, örtük değişkenin AVE değerinin karekökü, yapıdaki diğer tüm örtük değişkenlerle olan korelasyonundan daha büyük olmalıdır (Hair vd., 2019). AVE değerinin karekökü Tablo 1'de koyu renkli verilerdir. Bu değerler, bulundukları satır ve sütunlardaki diğer değerlerden büyük olarak hesaplanmıştır. Genel olarak yapılan incelemeler sonucunda modelin yapı, ayrım ve uyum geçerliliklerini sağladığı tespit edilmiştir.

\subsection{Bulgular}

Araştırma modelinin test edilmesi için yol analizi yapılmıștır. Araştırmanın amacı doğrultusunda oluşturulan hipotezlere ilişkin sonuçlar Tablo 5'te detaylı olarak gösterilmektedir.

Tablo 5: Yol Analizi Sonuçları

\begin{tabular}{|c|c|c|c|c|c|c|}
\hline Değişkenler & & Beta (B) & Std. Hata & $T$ & $P$ & Sonuç \\
\hline $\mathrm{H}_{1}$ Benlik İfade Eden & Marka $\longrightarrow \begin{array}{l}\text { Marka } \\
\text { Aşk1 }\end{array}$ & ,625 &, 045 & 13,820 & $0,000 * * *$ & $\begin{array}{l}\text { Kabul } \\
\text { Edildi }\end{array}$ \\
\hline $\mathrm{H}_{2}$ Marka Aşkı & $\longrightarrow \quad \begin{array}{c}\text { Marka } \\
\text { Sadakati }\end{array}$ &, 729 &, 028 & 26,287 & $0,000 * * *$ & $\begin{array}{l}\text { Kabul } \\
\text { Edildi }\end{array}$ \\
\hline $\mathrm{H}_{3}$ Marka Aşkı & P.A.A.İ & ,247 &, 052 & 4,747 & $0,000 * * *$ & $\begin{array}{l}\text { Kabul } \\
\text { Edildi }\end{array}$ \\
\hline $\mathrm{H}_{4}$ Benlik İfade Eden & Marka $\rightarrow$ P.A.A.I &, 115 &, 039 & 2,916 & $0,004 * *$ & $\begin{array}{l}\text { Kabul } \\
\text { Edildi }\end{array}$ \\
\hline $\mathrm{H}_{5}$ Marka Sadakati & P.A.A.İ &, 544 &, 055 & 9,880 & $0,000 * * *$ & $\begin{array}{l}\text { Kabul } \\
\text { Edildi }\end{array}$ \\
\hline
\end{tabular}

$\mathrm{p}=<0,001^{* * *}, \mathrm{p}=<0,01^{* *}, \mathrm{p}=<0,05^{*} ;$ P.A.A.İ: Pozitif Ağızdan Ağıza İletişim 
Benlik Ifade Eden Marka, Marka Aşkl, Pozitif Ă̆ızdan Ă̆ıza İletişim ve Marka Sadakati Arasındaki İlişkinin Incelenmesi: Paketlenmiş Ürün Kategorisinde Bir Araştırma

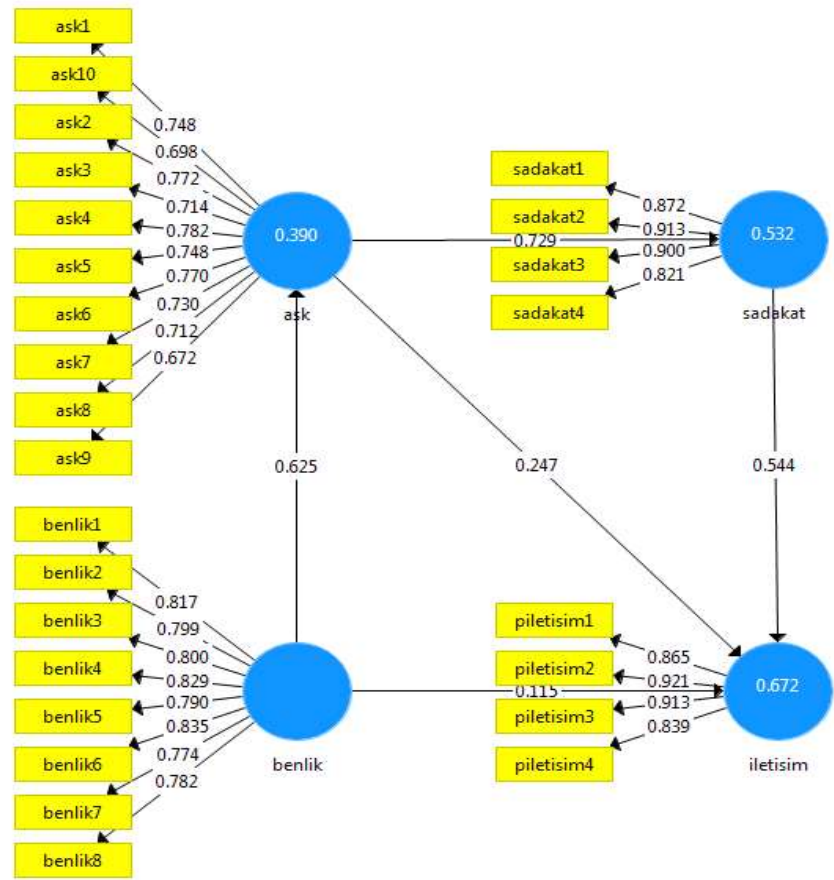

Şekil 2: Yol Analizi Modeli

Yol analizi sonuçları incelendiğinde bağımsız değişken olan benlik ifade eden markanın, marka aşkı ve pozitif ağızdan ağıza iletişimi pozitif yönde anlamlı olarak etkilediği ayrıca marka aşkı değişkeninin marka sadakati ve pozitif ağızdan ağıza iletişimi pozitif etkilediği belirlenmiştir. Bir başka değişken olan marka sadakatinin pozitif ağızdan ağıza iletişimi benzer bir şekilde pozitif şekilde etkilediği tespit edilmiştir. Bu kapsamda $\mathrm{H}_{1}, \mathrm{H}_{2}, \mathrm{H}_{3}, \mathrm{H}_{4}$ ve $\mathrm{H}_{5}$ hipotezleri kabul edilmiştir.

\section{Sonuç ve Tartışma}

Tatmin olmuş tüketicilerin marka aşkının markaya yönelik davranışlara olan etkisinin incelendiği bu çalışma, marka aşkı kavramına yönelik önceki çalışmalarla uyumlu olarak tatminden marka aşkına uzanan bir konsept sunmaktadır. Zira Carroll ve Ahuvia (2006) ve Fournier ve Mick (1999) gibi araştırmacılar marka aşkının tatminin (duygusal hazların) bir uzantısı olduğunu savunmaktadırlar. $\mathrm{Bu}$ yaklaşım markaya yönelik tüketici beklentilerinin karşılandığı durumlarda oluşan tatminden daha fazlasını içermektedir. Sternberg (1986) ve Fisher (2006) kişilerarası aşk kavramına yönelik değerlendirmelerinde aşka yönelik tutku, bağlılık ve romantizm öğelerini içeren kapsamlı bir yaklaşım sunmuş, sonraki tüketici araştırmaları da tatminden marka aşkına uzanan bir konsept geliştirmişlerdir. Buna göre tüketicilerin bir 
markaya yönelik beklenti karşılayan tatmin olgusunun dışında da markaya yönelik olumlu duygular geliştirmesi olağandır.

Çalışmada ilk olarak marka aşkının öncülü olarak kabul edilen benliği ifade eden markanın marka aşkına olumlu yönde pozitif etkisi olduğu sonucuna ulaşılmıştır. $\mathrm{Bu}$ sonuç, benliği ifade eden markaların ve benlik konsepti bağlantısının marka aşkı üzerinde pozitif etkisi olduğuna ilişkin literatürde yer alan çalışmalara tutarlılık içermektedir (Carroll ve Ahuvia, 2006; Hwang ve Kandampully, 2012). Erciş vd. (2018) çalışmalarında 300 katılımcıdan toplanan verilerle, benlik-marka bağının marka sadakati üzerindeki etkisinde, marka aşkı ve marka deneyiminin aracılık rolleri olduğu sonucuna ulaşmışlardır. Wallace vd. (2014), bir markaya ilişkin sevgi hisseden Facebook kullanıcılarına iliş̧kin yapmış oldukları çalışmalarında, "sevilen" markaların kendini ifade eden doğası ile marka aşkı arasında pozitif bir ilişki tespit etmiş̧lerdir.

Çalışmada ulaşılan diğer sonuçlara bakıldığında daha fazla marka aşkı hisseden tatmin olmuş tüketicilerin daha fazla sadakat ve pozitif ağızdan ağıza iletişim gösterdiklerine ilişkindir. Literatürde, tüketici tatminini marka aşkına doğru genişleten kapsamlı çalışmalar yer almaktadır (Fournier ve Mick, 1999; Shimp ve Madden, 1988; Ahuvia, 1993; Carroll ve Ahuvia, 2006). Bu sonuç literatürdeki çalışmalarla tutarlılık içermektedir. Carroll ve Ahuvia (2006), tatmin olmuş müşterilerin marka aşkının, olumlu ağızdan ağıza iletişimi ve marka sadakatini pozitif yönde etkilediği sonucuna ulaşmışlardır. Chaudhary (2018), marka sadakatinin ve pozitif ağızdan ağıza iletişimin hissedilen güçlü marka aşkından pozitif etkilendiği sonucuna ulaşmışlardır. Algharabat (2017) marka aşkının marka sadakati üzerindeki pozitif etkisini ifade etmiştir. Loureiro vd. (2017) marka aşkının, çevrimiçi marka katılımı ve çevrimiçi ağızdan ağıza iletişim arasında aracılık etkisi olduğu sonucuna ulaşmışlardır. Karjaluoto vd. (2016), marka aşkının hem çevrimiçi hem çevrimdışı ağızdan ağıza iletişim üzerinde pozitif etkisi olduğu sonucuna ulaşmışlardır. Wallace vd. (2014), benliği ifade eden ve aşk duyulan markalarla ilişki geliştiren tüketicilerin marka için pozitif ağızdan ağıza iletişim gerçekleştirme olasılıklarının daha yüksek olduğunu belirtmişlerdir.

Çalışmada elde edilen bir diğer sonuç benliği ifade eden markanın, pozitif ağızdan ağıza iletişim üzerinde pozitif bir etkisi olduğuna ilişkindir. Bu sonuç literatürde yer alan çalışmalarla tutarlıdır (Wallace vd., 2014; Ruane ve Wallace, 2015; Aziz ve Ngah, 2019). Carroll ve Ahuvia (2006), benliği-ifade eden markalarla pozitif ağızdan ağıza iletişim arasında anlamlı ve pozitif bir ilişki olduğu sonucuna ulaşmışlardır. Shachar vd. (2010), benliği-ifade eden markalardan yararlanan tüketicilerin, markalardan yararlanmak suretiyle anlamlı, değerli gördükleri ve hayatlarında iyi şeyleri hak ettiklerine inandıkları düşüncelerini söylemlerine yansıttıklarını belirtmektedirler.

Çalışmada son olarak marka sadakatinin pozitif ağızdan ağıza iletişim üzerinde pozitif bir etkisi olduğu sonucuna ulaşılmıştır. Bu sonuç yine literatürdeki çalışmalarla tutarlılık içermektedir. Bilgin (2017) restoran 
Benlik Ifade Eden Marka, Marka Aşkı, Pozitif Ă̆ızdan Ă̆ıza İletişim ve Marka Sadakati Arasındaki İlişkinin Incelenmesi: Paketlenmiş Ürün Kategorisinde Bir Araştırma

işletmeleri üzerine yapmış olduğu çalışmasında marka sadakatinin pozitif ağızdan ağıza iletişimi pozitif bir şekilde etkilediğini, benzer bir şekilde Carpenter ve Fairhurst (2005) müşteri sadakati ve pozitif ağızdan ağıza iletişim arasında güçlü bir ilişki olduğunu belirtmektedirler.

Gerçekleştirilen çalışma hem uygulayıcılar hem de pazarlama araştırmacıları için önemli sonuçlar ortaya çıkarmıştır. Öncelikle çalışma önceki çalışmalarla uyumlu olarak marka aşkına yönelik kapsamlı bir yapı önermiş ve belirlenen hipotezlerin tümünün doğrulanması marka aşkına ilişkin referans alınan çalışmadaki (Carroll ve Ahuvia, 2006) önerilen yapıyı (belirlenen değişkenler kapsamında) güçlendirmiş̧ir. Bu sonuç pazarlama araştırmalarında marka aşkına ilişkin önceki yapının geçerliliği ve geliştirilebileceği hakkında bilgiler üretmiştir. Ayrıca, tatmin olmuş tüketicilerin marka aşkına odaklanılması marka aşkı kavramına daha kapsamlı bir perspektif kazandırmış tatminden-marka aşkına uzanan yapıyı pekiştirmiştir. Çalışma uygulayıcılar açısından da sonuçlar üretmiştir. Marka aşkının öncülü olarak benlik ifade eden markalarla kurulan etkileşimin marka aşkını ve pozitif ağızdan ağıza iletişimi etkilemesi, işletmelerin hedef pazarında yer alan tüketicilerin kimlik öğelerinin anlaşılması ve buna uygun marka stratejileri geliştirilmesinin gerekliliğini ortaya koymaktadır. Bu sayede markaya yönelik güçlü bir aşk oluşturmak olanaklı olacaktır. Ayrıca işletmelerin markaya yönelik sadakat oluşturmak ve pozitif iletişim yaratmak adına tatmin olmuş tüketicilerin marka aşkına odaklanılması önerilmektedir. Bu sayede tutundurma faaliyetlerinin yarattığı maliyetler azaltılabilir, markaya yönelik alternatif yatırım olanakları arttır1labilir.

Çalışma, marka aşkının öncül ve sonuçlarına ilişkin bir model önerisi sunmuş bu kapsamda belirlenen örneklem üzerinde önceki çalı̧̧malarla uyumlu ve geçerli bir yapı ortaya koymuştur. Gelecek çalışmalarda marka aşkının öncüllerinin ve sonuçlarının farklı değişkenlerle incelenerek veya arttırılarak yeni bir model önerisi sunulması yararlı olabilir. Ayrıca gelecek çalışmalarda önerilen modelin farklı ve daha geniş bir örneklem üzerinde incelenmesinin marka aşkı literatürüne ve ayrıca uygulayıcılara farklı bir bakış açısı kazandıracağına inanılmaktadır.

\section{Kaynaklar}

Ahuvia, A. C. (1993). I Love It! Towards a Unifying Theory of Love Across Diverse Love Objects, Doctoral dissertation, University of Michigan.

Albert, N., Merunka, D. (2013). The Role of Brand Love in Consumer-Brand Relationships. Journal of Consumer Marketing, 30(3), 258-266.

Algharabat, R. (2017). Linking Social Media Marketing Activities with Brand Love: The Mediating Role of Self-Expressive Brands. Kybernetes, 46(10),1801-1819.

Aron, A., Aron, E. N. (1985). Love and the Expansion of Self: Understanding Attraction and Satisfaction. Washington: Hemisphere publishing. 
Aron, A., Paris, M., Aron, E. N. (1995). Falling in Love: Prospective Studies of Self-Concept Change. Journal of Personality and Social Psychology, 69, $1102-1112$.

Aziz, N.A., Ngah, H. (2019). The Effect of Self Expressive Value and Perceived Value on Malaysian Cosmetic Brand Loyalty: The Mediating Role of Brand Identification \& Word of Mouth. Asia-Pacific Management Accounting Journal, 14(1),151-178.

Backman, S. J., Crompton, J. L. (1991). The Usefulness of Selected Variables for Predicting Activity Loyalty. Leisure Sciences, 13(3), 205-220.

Bagozzi, R. P., Batra, R., Ahuvia, A. (2017). Brand Love: Development and Validation of a Practical Scale. Marketing Letters, 28(1), 1-14.

Batra, R., Ahuvia, A., Bagozzi, R. P. (2012). Brand Love. Journal of Marketing, 76, 1-16.

Behara, R., Fontenot, G., Gresham, A. (2002). Customer Process Approach to Building Loyalty. Total Qual. Manage., 13(5), 603-611.

Bilgin, Y. (2017). Restoran İşletmelerinde Hizmet Kalitesi, Müşteri Memnuniyeti ve Müşteri Sadakatinin Ağızdan Ağıza Pazarlamaya Etkisi. İşletme Araştırmaları Dergisi, 9(4), 33-62.

Carpenter, J., Fairhurst, A. (2005). Consumer Shopping Value, Satisfaction, and Loyalty for Retail Apparel Brands. Journal of Fashion Marketing and Management, 9(3), 256-269.

Carroll, B. A., Ahuvia, A. C. (2006). Some Antecedents and Outcomes of brand love. Market Letter, 17(2), 79-89.

Casielles, R. V., Álvarez, L. S., Del Rio-Lanza, A. B. (2013). The Word of Mouth Dynamic: How Positive (and Negative) WOM Drives Purchase Probability An Analysis of Interpersonal and Non-Interpersonal Factors. Journal of Advertising Research, 1, 43-60.

Cătălin, M. C., Andreea, P. (2014). Brands as a Mean of Consumer SelfExpression and Desired Personal Lifestyle. Procedia-Social and Behavioral Sciences, 109(2014), 103-107.

Chaudhary, A. H. (2018). Retracted Article: Brand Love: Fiction or reality?. Journal of Strategic Marketing, 26(8), 1-11.

Cunningham, R. M. (1961). Customer Loyalty to Store and Brand. Harvard Business Review, 39(6), 127-137.

Czellar, S., Sprott, D. E., Spangenberg, E. R., Raska, D. (2010). Consumer Reactions to Self-Expressive Brand Display, Les Cahiers de Recherche, HEC, France.

Day, G. S. (1969). A Two-Dimensional Concept of Brand Loyalty. Journal of Advertising Research, 9(3), 29-35.

Demirăg, B., Durmaz, Y. (2020). Marka Yönetimi. (1 Basım). İstanbul: Hiper Yayın.

Demirağ, B., Durmaz, Y. (2019). Algılanan Hizmet Kalitesinin Algılanan Değer ve Tutumsal Marka Sadakati Üzerindeki Etkisinin İncelenmesi: 5 Yıldızlı 
Benlik Ifade Eden Marka, Marka Aşkı, Pozitif Ă̆ızdan Ă̆ıza İletişim ve Marka Sadakati Arasındaki İlişkinin Incelenmesi: Paketlenmiş Ürün Kategorisinde Bir Araştırma

Sayfiye ve Şehir Otelleri Örneği. Uluslararası Toplum Araştırmaları Dergisi, 11(18), 695-726.

Erciş, A., Aykut, O. H., Yıldız, T. (2018). The Mediation Role of Brand Love and Experience in the Effect of Self-Brand Connection on the Brand Loyalty. Research Journal of Business and Management (RJBM), 6(2), 137-148.

Evanschitzky, H., Wunderlich, M. (2006). An Examination of Moderator Effects in the Four-Stage Loyalty Model. Journal of Service Research, 8(4), 330-345.

Ferguson, R. J., Paulin, M., Bergeron, J. (2009). Customer Sociability and the Total Service Experience. Journal of Service Management, 21(1), 25-44.

Fisher, H. (2006). The Drive to Love: The Neural Mechanism for Mate Selection. In Sternberg, R. J. \& Weis, K. E. (Eds.), The New Psychology of Love (pp. 87-115). New Haven, CT: Yale University Press.

Fornell, C., Larcker, D. F. (1981). Structural Equation Models With Unobservable Variables and Measurement Error: Algebra and Statistics. Journal of Marketing Research, May, 382-388.

Fournier, S. (1998). Consumers and Their Brands: Developing Relationship Theory in Consumer Research. Journal of Consumer Research, 24(4), 343-373.

Fournier, S., Mick, D. G. (1999). Rediscovering Satisfaction. Journal of Marketing, 63(4), 5-23.

Glasman, L. R., Albarracin, D. (2006). Forming Attitudes that Predict Future Behavior: A Meta-Analysis of the Attitude-Behavior Relation. Psychological Bulletin, 132(5), 778- 822.

Hair, J. F., Risher, J. J., Sarstedt, M., Ringle, C. M. (2019). When to use and how to Report the Results of PLS-SEM. European Business Review, 31(1), 2-24.

Hair, J. F., Sarstedt, M., Ringle, C. M., Mena, J. A. (2012). An Assessment of the use of Partial Least Squares Structural Equation Modeling in Marketing Research. Journal of the Academy of Marketing Science, 40(3), 414-433.

Han, X., Kwortnik, R. J., Wang, C. (2008). Service Loyalty: An Integrative Model and Examination Across Service Contexts. Journal of Service Research, 11, 22-42.

Harary, F., Lipstein, B. (1962). The Dynamics of Brand Loyalty: a Markovian Approach. Operations Research, 10(1), 19-40.

Hu, L. T., Bentler, P. M. (1999). Cutoff Criteria for Fit Indexes in Covariance Structure Analysis: Conventional Criteria Versus New Alternatives. Structural Equation Modeling: A Multidisciplinary Journal, 6(1), 1-55.

Huang, C. (2017). The Impacts of Brand Experiences on Brand Loyalty: Mediators of Brand Love and Trust. Management Decision, 55(5), 915934. 
Hwang, J., Kandampully, J. (2012). The Role of Emotional Aspects in Younger Consumer Brand Relationships. Journal of Product \& Brand Management, 21(2), 98-108.

Ilaw, M. A. (2014). Who You Are Affects What You Buy: The Influence of Consumer Identity on Brand Preference. The Elon Journal of Undergraduate Research in Communications, 5(2), 5-16.

Jacoby, J., Kyner, D. B. (1973). Brand Loyalty Versus Repeat Purchasing Behaviour. Journal of Marketing Research, 10, 1-9.

Jones, T. O., Sasser, W. E. (1995). Why Satisfied Customers Defect. Harvard Business Review, 73(6), 88.

Kaiser, H. F. (1974). An Index of Factorial Simplicity. Psychometrik, 39(1), 3136.

Kalaycı, Ş. (2005). SPSS Uygulamalı Çok Değişkenli İstatistik Teknikleri. İstanbul: Asil Yayın Dağıtım.

Kang, A. (2015). Brand Love-Moving Beyond Loyalty An Empirical Investigation of Perceived Brand Love of Indian Consumer. Arab Economics And Business Journal, 10, 90-101.

Karjaluoto, H., Munnukka, J., Kiuru, K. (2016). Brand Love and Positive Word of Mouth: The Moderating Effects of Experience and Price. Journal of Product and Brand Management, 25(6), 527-537.

Kement, Ü., Çavuşoğlu, S. (2017). Hafızaya Yönelik Müşteri Deneyimlerinin Müşteri Sadakatine Etkisi: Yeşil Oteller Örneği. Uluslararası Sosyal ve Ĕgitim Bilimleri Dergisi, 4(8), 172-194.

Konadu, A. Y. (2018). Examining the Relationship of Brand Love and Brand Loyalty to Luxury Fashion Brands in Russia. Master Thesis, St. Petersburg State University, Russia.

Loureiro, S., Gorgus, T., Kaufmann, H. (2017). Antecedents and Outcomes of Online Brand Engagement: The Role of Brand Love on Enhancing Electronic-Word-of-Mouth. Online Information Review, 41( 7), 9851005.

Maisam, S., Mahsa, R. (2016). Positive Word of Mouth Marketing: Explaining the Roles of Value Congruity and Brand Love. Journal of Competitiveness, 8(1), 19-37.

Mazodier, M., Merunka, D. (2014). Beyond Brand Attitude: Individual Drivers of Purchase for Symbolic Cobranded Products. Journal of Business Research, 67, 1552-1558.

Niyomsart, S., Khamwon, A. (2016). Brand Love, Brand Loyalty, And Word of Mouth: A Case of Airasia. Conference of the International Journal of Arts \& Sciences, 9(1), 263-268.

Oliver, R.L. (1997). Loyalty and Profit: Long-Term Effects of Satisfaction. Satisfaction: A Behavioural Perspective on the Consumer. McGraw-Hill Companies, Inc., New York, NY. 
Benlik Ifade Eden Marka, Marka Aşkı, Pozitif Ă̆ızdan Ă̆ıza İletişim ve Marka Sadakati Arasındaki İlişkinin Incelenmesi: Paketlenmiş Ürün Kategorisinde Bir Araştırma

Pandowo, A. (2016). How to Create Brand Love in Private Label: The Role of Satisfaction as Intervening Variable. Journal of Marketing Management, $4(2), 81-91$.

Phau, I., Lau, K. C. (2000). Brand Personality and Consumer Self-Expression: Single or Dual Carriageway?. Brand Management, 8(6), 428-444.

Purnasari, H., Yuliando, H. (2015). How Relationship Quality on Customer Commitment Influences Positive e-WOM. Agriculture \&Agricultural Science Procedia, 3, 149-153.

Radder, L., Han, X. (2013). Perceived Quality, Visitor Satisfaction and Conative Loyalty in South African Heritage Museums. International Business \& Economics Research Journal, 12(10), 1261-1271.

Ruane, L., Wallace, E. (2015). Brand Tribalism and Self-Expressive Brands: Social Influences and Brand Outcomes. Journal of Product \& Brand Management, 24(4), 333-348.

Sarkar, A., Pradhan, S. (2016). Examining the Roles Played by a Store Satisfaction-Love Framework in Shaping the Influence of Store Loyalty Programs. Management Research Review, 39(8), 879-898.

Saha, G. C., Theingi, A. (2009). Service Quality, Satisfaction, and Behavioural Intentions: A Study of Low-Cost Airline Carriers in Thailand. Managing Service Quality, 19(3), 350-372.

Shachar, R., Erdem, T., Cutright, K. M., Fitzsimons, G. J. (2010). Brands: The Opiate of the Nonreligious Masses?. Marketing Science, Articles in Advance, 1-19.

Shimp, T. A., Madden, T. J. (1988). Consumer-Object Relations: A Conceptual Framework Based Analogously on Sternberg's Triangular Theory of Love. ACR North American Advances. Provo, UT: Association for Consumer Research, 163-168.

Song, H., Wang, J., Han, H. (2019). Effect of Image, Satisfaction, Trust, Love, and Respect on Loyalty Formation for Name-Brand Coffee Shops. International Journal of Hospitality Management, 79, 50-59.

Steinhart, Y., Kamins, M., Mazursky, D., Noy, A. (2014). Effects of Product Type and Contextual Cues on Eliciting Naive Theories of Popularity and Exclusivity. Journal of Consumer PsychologY, 24(4), 472-483.

Sternberg, R. J. (1986). A Triangular Theory of Love. Psychological Review, 93(2), 119-135.

Sweeney, J. C., Soutar, G. N., Mazzarol, T. (2008). Factors Influencing Word of Mouth Effectiveness: Receiver Perspectives. European Journal of Marketing, 42(3/4), 344-364.

Taylor, D. G., Strutton, D., Thompson, K. (2012). Self-Enhancement as a Motivation for Sharing Online Advertising. Journal of Interactive Marketing, 12(2), 28. 
Unal, S., Aydin, H. (2013). An Investigation on the Evaluation of the Factors Affecting Brand Love. Procedia-Social and Behavioral Sciences, 92(2013), 76-85.

Vries, L., Peluso, A. M., Romani, S., Leeflang, P. S. H., Marcati, A. (2017). Explaining Consumer Brand-Related Activities on Social Media: An Investigation of the Different Roles of Self-Expression and Socializing Motivations. Computers in Human Behavior, 75, 1-29.

Wallace, E., Buil, I., De Chernatony, L. (2014). Consumer Engagement with Self-Expressive Brands: Brand Love and WOM Outcomes. Journal of Product \& Brand Management, 23(1), 33-42.

Wilklie, W. L. (1990). Consumer Behavior. John and Sons Publications. Newbury Park, CA, 784.

Yasvari, T. H., Ghassemi, R. A., Rahrovy, E. (2012). Influential Factors on Word of Mouth in Service Industries (The case of Iran Airline Company). International Journal of Learning and Development, 2(5), 227-242.

Yaşlıŏlu, M. M. (2017). Sosyal Bilimlerde Faktör Analizi ve Geçerlilik: Keşfedici ve Doğrulayıcı Faktör Analizlerinin Kullanılması. İstanbul Üniversitesi Işletme Fakültesi Dergisi, 46, 74-85. 